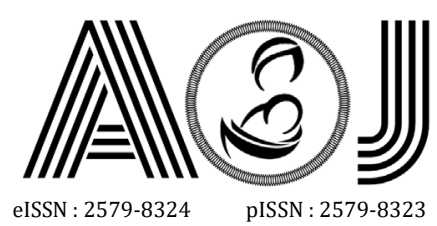

\title{
RESEARCH
}

\section{The Relationship Between Magnesium Level in Pregnancy with Gestational Diabetes Mellitus}

\author{
Syntia Ambelina1, Dovy Djanas ${ }^{2}$, Hafni Bachtiar ${ }^{3}$
}

Affiliation author: 1. Obstetrics and Gynecology, Faculty of Medicine, Andalas University, Dr. M. Djamil Central General Hospital Padang; 2. Sub Division of Maternal Fetal Medicine, Obstetrics and Gynecology Department, Faculty of Medicine, Andalas University, Dr. M. Djamil Central General Hospital Padang; 3. Public Health Department, Faculty of Medicine, Andalas University Padang

Correspondence to: Syntia Ambelina, email: osynambelina@gmail.com, Hp: 082392042745

\section{Abstract}

Introduction : Magnesium is one of important micronutrients in pregnancy. Pregnant women needs higher magnesium intake than non-pregnant women at similar age. Decreased blood and cellular magnesium level was related to insulin resistance.

Objective : To determine relationship between mean magnesium level in pregnant women with incidence of gestational diabetes mellitus.

Methods: This was quantitative analytic study using cross sectional comparative design conducted in 8 Primary Health Care in Padang and 5 General Hospital in West Sumatra. This study was done from December 2019 until March 2020. Total sample collected was 36 samples consisted of 18 pregnant mother with gestational diabetes mellitus and 18 control sample with normal pregnancy, both were in gestational age between 24-28 weeks. Statistical analysis was done using independent sample T-test.

Results : Mean magnesium level of pregnant mother with gestational diabetes mellitus was $1.85 \pm 0.12$ $\mathrm{mg} / \mathrm{dL}$, while in control sample was $2.10 \pm 0.15 \mathrm{mg} / \mathrm{dL}$. Statistical result using independent sample $T$ test showed significant correlation between mean magnesium level and incidence of gestational diabetes mellitus with $p<0.001$ ( $p$ value $<0.05$ )

Conclusion : Magnesium level during pregnancy is related to gestational diabetes mellitus incidence. Keywords: magnesium level, pregnant women, gestational diabetes mellitus

\section{INTRODUCTION}

Maternal mortality rate is one of indicator for community wellbeing in a country. Based on World Health Organization (WHO) data, maternal mortality rate globally in 2015 was 216 per 100.000 live births or total estimated maternal death was 303.000 cases. While maternal mortality rate in developing country was 302.000 cases. ${ }^{1}$ Indonesia is one of countries with high maternal mortality rate between ASEAN countries. Based on Indonesia Demographic and Health Survey in 2012, maternal mortality rate in Indonesia was 359 per 100.000 live births. This data is used as reference to achieve maternal mortality rate goal according to Sustainable Development Goals (SDGs) that is 70 per 100.000 live births in $2030 .^{2}$

Several efforts could be done to reduce maternal mortality rate and neonatal mortality rate, one of them was providing adequate nutrition. Adequate nutrition during pregnancy 


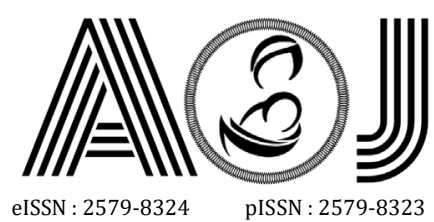

eISSN : 2579-8324
pISSN : 2579-8323

would support successful pregnancy. Among nutritional needs of pregnant women during pregnancy was micronutrients. This adequacy of micronutrients could not only fulfilled directly from food, but also from food supplements. ${ }^{3}$

One of important micronutrients in pregnancy was magnesium. ${ }^{3}$ Magnesium is a second most abundant intracellular cation in body which played roles in enzyme functioning and acted as cofactors in more than 600 enzymatic reaction and also as activator of 200 enzymes. ${ }^{4,5}$ Serum magnesium level decreased during pregnancy, due to increased demand and excretion of magnesium in kidney. ${ }^{3}$ Pregnant women needs daily magnesium intake 40 $\mathrm{mg}$ more than non-pregnant women at the same age, where magnesium intake needed in non-pregnant women was $310 \mathrm{mg}$ daily for age between 19-30 years and $320 \mathrm{mg}$ daily for age between 31-50 years. ${ }^{5}$

WHO stated that magnesium deficiency was frequently found either in developed or developing countries. Hypomagnesium prevalence in general population was estimated around $2.5-15 \% .{ }^{6}$ Magnesium deficiency during pregnancy was not only become nutritional problem for mother and fetus, but more severe effects during pregnancy could also occured. Magnesium level could decrease gradually in 4 months or more before manifestation of hypomagnesaemia symptoms such as nausea and vomiting, decreased appetite, fatique, and muscle cramp. ${ }^{7}$

Magnesium is a mineral that affects cell responses such as secretion, binding, and receptor activity. Magnesium is also a cofactor for enzymatic reactions involved in carbohydrate metabolism. Decreased blood and cellular magnesium level is correlated to insulin resistance. ${ }^{5,8}$

Diabetes is a metabolic disease marked by hyperglycaemia due to defect of insulin secretion, insulin action, or both. ${ }^{9}$ Gestational diabetes mellitus is one of complicating medical condition that could occur during pregnancy. Gestational diabetes mellitus incidence rate was about $2-5 \%$ of all pregnancy and resulted in more than 200.000 cases annually. ${ }^{10}$ More than half women with gestational diabetes suffered from subsequent diabetes overt 20 years later, and more evidences proved long term complication such as obesity and diabetes in offsprings. ${ }^{11}$ Gestational diabetes mellitus is one of strongest predictor of pre-diabetic and type 2 diabetes mellitus. ${ }^{12}$

Hypomagnesaemia incidence in patients with diabetes was about $13,5-47,7 \%{ }^{13}$ Hypomagnesium in diabetes was correlated with development and also severity of diabetes. ${ }^{14}$ Therefore, authors was interested to study "the relationship between magnesium level in pregnancy with gestational diabetes mellitus".

\section{METHODS}




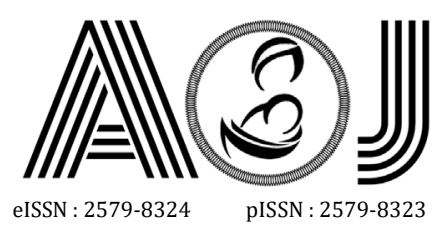

Editorial Room Andalas Obstetrics and Gynecology Journal, $3^{\text {rd }}$ floor of KSM of Obstetrics and Gynecology,

RSUP DR. M. Djamil Padang, Jl. Perintis Kemerdekaan Padang, Sumatera Barat 25127

This was quantitative analytic study using cross sectional comparative design conducted in 8 Primary Health Care in Padang and 5 General Hospital in West Sumatra. This study was done from December 2019 until March 2020. Total sample collected was 36 samples consisted of 18 pregnant mother with gestational diabetes mellitus and 18 control sample with normal pregnancy, both were in gestational age between 24-28 weeks. Vein blood samples were collected in two occasions two hours apart to assess fasting blood glucose, 2 hour post prandial blood glucose, and magnesium level. Laboratory result were then analyzed statistically using independent sample $T$ test.

Before study was conducted, ethical clearance was submitted to Ethical Comittee of Medical Faculty Andalas University, and had been approved for ethical clearance with No. 015/KEP/FK/2020.

\section{RESULTS}

\section{Study Respondents Characteristics}

Characteristics of study respondents, consisted of maternal age, level of education, gravidity, BMI before pregnancy, and BMI at pregnancy, could be seen in Table 1.

Table 1. Respondents Characteristics

\begin{tabular}{|c|c|c|c|}
\hline Characteristic & $\begin{array}{l}\text { Gestational Diabetes } \\
\text { Mellitus }(n=18)\end{array}$ & $\begin{array}{l}\text { Control } \\
(n=18)\end{array}$ & p value* \\
\hline Maternal Age (years), Mean \pm SD & $30.17 \pm 3, .56$ & $28.06 \pm 5.04$ & 0.157 \\
\hline Level of education, $f(\%)$ & & & 0.526 \\
\hline Junior High School & $0(0 \%)$ & $1(5.6 \%)$ & \\
\hline Senior High School & $15(83.3 \%)$ & $13(72.2 \%)$ & \\
\hline Undergraduates & $3(16.7 \%)$ & $4(22.2 \%)$ & \\
\hline Gravidity, $f(\%)$ & & & 0.914 \\
\hline Nullipara & $4(22.2 \%)$ & $5(27.8 \%)$ & \\
\hline Primipara & $7(38.9 \%)$ & $5(27.8 \%)$ & \\
\hline Multiparas & $7(38.9 \%)$ & $8(44.5 \%)$ & \\
\hline $\begin{array}{l}\text { BMI before pregnancy }\left(\mathrm{kg} / \mathrm{m}^{2}\right) \text {, Mean } \\
\pm \text { SD }\end{array}$ & $26.12 \pm 3.93$ & $23.49 \pm 2.24$ & 0.020 \\
\hline BMI before pregnancy, $f(\%)$ & & & 0.212 \\
\hline Normal & $10(55.6 \%)$ & $15(83.3 \%)$ & \\
\hline Overweight & $5(27.8 \%)$ & $3(16.7 \%)$ & \\
\hline Obesity 1 & $2(11.1 \% \%)$ & $0(0 \%)$ & \\
\hline Obesity 2 & $1(5.6 \%)$ & $0(0 \%)$ & \\
\hline Obesity 3 & $0(0 \%)$ & $0(0 \%)$ & \\
\hline
\end{tabular}

*significant if $p<0,05$

Based on table above, it could be seen that most of pregnant women in both group had graduated from senior high school. Statistical analysis showed that there were no significant 


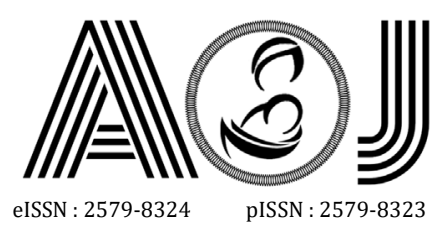

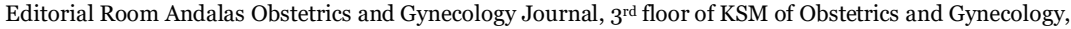

RSUP DR. M. Djamil Padang, Jl. Perintis Kemerdekaan Padang, Sumatera Barat 25127

relationship between maternal ages, gravidity, and BMI category before pregnancy and incidence of gestational diabetes mellitus. But there were significant differences between mean BMI before pregnancy between both groups.

\section{Normality Test}

Normality test was done using Shapiro Wilk test to determine whether data was distributed normally $(p>0,05)$ or not $(p<0,05)$. Normality test result could be seen in Table 2 .

Table 2. Normality Test

\begin{tabular}{lllll}
\hline Variable & Group & $\mathbf{n}$ & Mean \pm SD & p value* \\
\hline Magnesium level $(\mathbf{m g} / \mathrm{dL})$ & Gestational Diabetes Melitus & 18 & $1.85 \pm 0.12$ & $0.741^{\mathrm{a}}$ \\
& Kontrol & 18 & $2.10 \pm 0.15$ & $0.071^{\mathrm{a}}$ \\
\hline
\end{tabular}

*Data is distributed normally if $p>0,05$

ashapiro-Wilk test

Based on Table 2, it is known that magnesium level in group of pregnant women with gestational diabetes mellitus and pregnant women with normal blood glucose level was distributed normally with $p>0.05$. Then, these data was analyzed using independent sample T-test described in Table 3.

\section{Correlation between Mean Magnesium Level with Gestational Diabetes Mellitus}

Correlation between mean magnesium level with gestational diabetes mellitus incidence could be seen in Table 3.

Table 3. Correlation between Mean Magnesium Level with Gestational Diabetes Mellitus

\begin{tabular}{lllll}
\hline Group & $\mathbf{n}$ & $\begin{array}{l}\text { Magnesium Level }(\mathrm{mg} / \mathrm{dL}) \\
\text { Mean } \pm \text { SD }\end{array}$ & $\begin{array}{l}\text { Min-Max } \\
\text { (mg/dL) }\end{array}$ & p value* \\
\hline $\begin{array}{l}\text { Gestational Diabetes Mellitus } \\
\text { Kontrol }\end{array}$ & 18 & $1.85 \pm 0.12$ & $1.65-2.15$ & $<0.001$ \\
& 18 & $2.10 \pm 0.15$ & $1.79-2.29$ & \\
\hline
\end{tabular}

*Independent sample T test

Based on Table 3, it is known that mean geometric of magnesium level in gestational diabetes mellitus was $1.85 \pm 0.12 \mathrm{mg} / \mathrm{dL}$, which was lower than control $(2.10 \pm 0.15 \mathrm{mg} / \mathrm{dL})$. Statistical test using independent sample T-test showed $p<0.001$ ( $p$ value $<0.05$ ) which meant that there were significant correlation between mean magnesium level with gestational diabetes mellitus incidence.

\section{DISCUSSION}




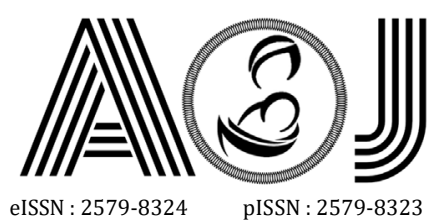

eISSN : 2579-8324
pISSN : 2579-8323
ANDALAS OBSTETRICS AND GYNECOLOGY JOURNAL

Address for Correspondence:

Editorial Room Andalas Obstetrics and Gynecology Journal, $3^{\text {rd }}$ floor of KSM of Obstetrics and Gynecology,

RSUP DR. M. Djamil Padang, Jl. Perintis Kemerdekaan Padang, Sumatera Barat 25127

Website:

http://jurnalobgin.fk.unand.ac.id/index.php/JOE

\section{Mean Magnesium Level of Pregnant Women}

Based on independent sample T-test, it is known that mean magnesium level in pregnant women with gestational diabetes mellitus was $1.85 \pm 0.12 \mathrm{mg} / \mathrm{dL}$, while mean magnesium level in pregnant women with normal blood glucose level was higher, that was $2.10 \pm 0.15 \mathrm{mg} / \mathrm{dL}$. This study was supported by previous study by Syaikh, stating that serum magnesium level was decreased during pregnancy, due to increased demand and magnesium excretion in kidney. Therefore, pregnant mother needs higher magnesium intake than nonpregnant women at the same age. Meanwhile, study by Mishu found that mean magnesium level in gestational diabetes mellitus was $1.3884 \pm 0.255 \mathrm{mg} / \mathrm{dL}$ and in normal pregnant women was $1.6651 \pm 0.304 \mathrm{mg} / \mathrm{dL}^{15}$

Magnesium is fourth most abundant cation in human body, related to carbohydrate and lipid metabolism. ${ }^{16}$ Magnesium played important role in fetal and maternal wellbeing since it is one of important element for normal embryogenesis and fetal growth. Lacking of this element would increase mortality and morbidity rate of maternal, embryo, and neonates. ${ }^{17}$

Pregnant women tend to have lower magnesium level than non-pregnant women due to increased maternal and developing fetal needs and also increased magnesium excretion by kidney. Magnesium excretion in pregnant women were $25 \%$ more than non-pregnant women due to increased glomerular filtration rate in the second and third trimester of pregnancy. ${ }^{15}$

\section{Correlation between Mean Magnesium Level with Gestational Diabetes Mellitus}

This study found that mean magnesium level in pregnant women with gestational diabetes mellitus was lower, that was $1.85 \pm 0.12 \mathrm{mg} / \mathrm{dL}$ than mean magnesium level in pregnant women with normal blood glucose level $(2.10 \pm 0.15 \mathrm{mg} / \mathrm{dL})$. Statistical analysis using independent sample T-test found $p$ value $<0,001$ ( $p$ value $<0.05$ ), meant that there were significant difference of magnesium level between pregnant women with gestational diabetes mellitus and pregnant women with normal blood glucose level. Therefore, other than routine blood glucose level in pregnant women, magnesium level also need to be assessed as one of parameter to predict incidence risk of gestational diabetes mellitus.

This study result was similar to case controlled study result by Mishu evaluating correlation between serum magnesium with gestational diabetes mellitus in 172 pregnant women in Bangladesh. Mishu found that magnesium level significantly lower $(p<0.001)$ in gestational diabetes mellitus case $(1.3884 \pm 0.255 \mathrm{mg} / \mathrm{dL})$ than healthy pregnant women $(1.6651 \pm 0.304 \mathrm{mg} / \mathrm{dL})$ in the second trimester of pregnancy. Similar result was also found significant $(p<0.001)$ in third trimester of pregnancy. Thus it could be concluded that assessment of serum magnesium level should be done in each gestational diabetes mellitus 


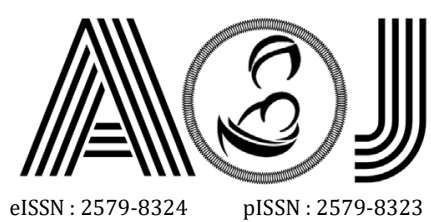

eISSN : 2579-8324
pISSN : 2579-8323

case to reduce incidence of complications related to magnesium and also for timely administration of intervention. ${ }^{15}$

This study was also supported by previous study by Bardicef ${ }^{18}$, Takaya ${ }^{19}$, and Yinsong Wang ${ }^{20}$. They found that pregnant women with gestational diabetes mellitus had lower plasma magnesium level than normal pregnant women. Decreased serum magnesium level could be caused by magnesium depletion due to diuretic osmotic and also indirect hormonal effect. Low serum magnesium level seen in diabetes mellitus population could be due to consequences of insulin resistance and decreased intake of food containing magnesium. ${ }^{18,19,20}$

On the contrary, Musavi studied 387 pregnant women and found that there were no significant differences between pregnant women with gestational diabetes mellitus and control in terms of serum magnesium concentration. ${ }^{21}$ Tasdemir also found that there were no statistically significant differences in serum magnesium concentration between healthy pregnant women and pregnant women with gestational diabetes mellitus. ${ }^{15}$

Further, prospective study by Nabouli which includes 99 pregnant women found that serum magnesium concentration in pregnant women with gestational diabetes mellitus was lower than normal pregnant women $(0.89 \pm 0.1 \mathrm{mmol} / \mathrm{L}$ vs $0.92 \pm 0.2 \mathrm{mmol} / \mathrm{L})$. Yet, this founding is not statistically significant, $p=0.51$. Nabouli study result supported hypothesis that low plasma magnesium level in pregnant women could induce insulin resistance. ${ }^{22}$

Gestational diabetes mellitus could not only established using low total serum magnesium level. Low total serum magnesium level in patients diagnosed with gestational diabetes mellitus and importance of magnesium in regards of insulin resistance risk should be supported by larger study to explain exact role of magnesium in the pathophysiology of gestational diabetes mellitus. ${ }^{22}$

Vijay did a case controlled study trial in 90 pregnant women. Study result showed that mean serum magnesium level was lower in gestational diabetes mellitus group compared to normal group with $p$ value $<0.0001$. Vijay concluded that hypomagnesaemia is an underlying factor in glucose metabolic alteration in pregnant women and supplemental magnesium could help gestational diabetes mellitus patients in controlling metabolic profile and pregnancy outcome. ${ }^{8}$

Decreased magnesium level in blood circulation is related with insulin resistance and risk factor of type 2 diabetes mellitus. ${ }^{23,24}$ Bardicef found that depletion of intracellular magnesium could occur especially in pregnant women with gestational diabetes mellitus. ${ }^{18}$ Serum magnesium level was significantly lower in patients with gestational diabetes mellitus than normal pregnant women. Hypomagnesaemia could be caused by low food intake, increased nutritional needs, or osmotic diuretic and due to indirect hormonal effect. ${ }^{25,26}$

Hyperglycaemia is related to stress oxidative and impaired metabolism. ${ }^{27}$ Poor glycaemic control is a risk factor for magnesium decrease. Vijay found negative correlation 


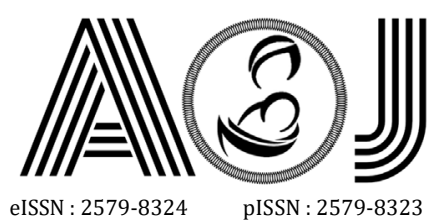

eISSN : 2579-8324
pISSN : 2579-8323

between serum magnesium level and plasma glucose 2 hours postprandial in gestational diabetes mellitus group $(p<0.05)$ and normal control group $(p<0.05)$, which showed that decreased serum magnesium level is a predictor for increased blood glucose level in pregnant women. ${ }^{8}$

Based on cohort by Yang to 116 pregnant women for $15.6 \pm 2.0$ months, it is found that patients with type 2 diabetes mellitus had lowest serum magnesium level (0.65 [0.63-0.68] $\mathrm{mMol} / \mathrm{L}$ ), yet statistical analysis showed no significant difference of magnesium level between gestational diabetes mellitus group $(0.70[0.65-0.70] \mathrm{mMol} / \mathrm{L})$ and normal control group $(0.70$ $[0.65-0.70] \mathrm{mMol} / \mathrm{L})(\mathrm{p}=0.073){ }^{28}$

Insulin resistance is a significant predictor for gestational diabetes mellitus and type 2 diabetes mellitus. Meanwhile, serum magnesium level after delivery is also a predictor of type 2 diabetes mellitus in women with history of gestational diabetes mellitus. Magnesium could affect hormone release and activity that could help controlling blood glucose level through tyrosine kinase. Further, insulin partially regulates accumulation of intracellular magnesium. ${ }^{29,30}$

Study by Asemi $Z$ showed that administration of supplemental magnesium in women with gestational diabetes mellitus significantly increase magnesium level and decreased insulin resistance risk, therefore effective glucose tolerance was maintained. Thus, early detection of hypomagnesaemia condition and magnesium replacement therapy in pregnant women could be done to decrease complications in pregnancy. ${ }^{31}$

\section{CONCLUSION}

Mean magnesium level in pregnant women with gestational diabetes mellitus is lower than pregnant women with normal blood glucose level. There were significant difference of mean magnesium level between pregnant women with gestational diabetes mellitus and pregnant women with normal blood glucose level.

\section{RECOMMENDATION}

1. Assessment of magnesium level could be used as one predictor of gestational diabetes mellitus.

2. Efforts to increase magnesium level could be done to prevent gestational diabetes mellitus, for example through magnesium supplementation and increased magnesium-rich food intake, and through increased maternal understanding about the importance of magnesium in pregnancy. 


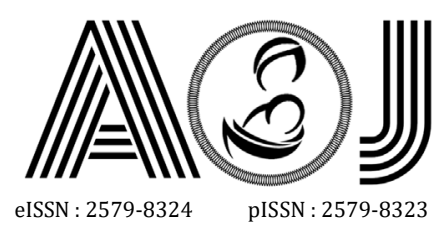

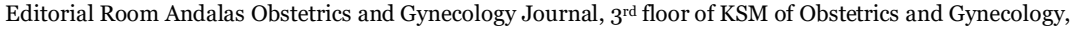
RSUP DR. M. Djamil Padang, Jl. Perintis Kemerdekaan Padang, Sumatera Barat 25127

Website:

http://jurnalobgin.fk.unand.ac.id/index.php/JOE

\section{REFFERENCES}

1. ASEAN. Asean statistical report on millennium development goals. 2017

2. Kemenkes RI. Data dan informasi profil kesehatan Indonesia 2017. Infodatin. 2017.

3. Syaikh K, Das CM, Baloch GH, Abbas T, Fazlani K and Jaffery MH. Magnesium associated complications in pregnant women. World Appl. Sci. J. 2012; 17(9): 107478.

4. Lammi-Keefe, Carol \& Couch, Sarah \& H. Philipson, Elliot. Handbook of Nutrition and Pregnancy. 2008; 191-109.

5. Lynne M. Dalton, Deirdre M. Ni Fhloinn, Gergana T. Gaydadzhieva, Ola M. Mazurkiewicz, Heather Leeson, Ciara P. Wright. Magnesium in Pregnancy. Nutrition Reviews. 2016; 74(9): 549-557.

6. Dalton LM, Fhloinn DM, Gaydadzhieva GT, Mazurkiewicz OM, Leason H and Wright CP. Magnesium in Pregnancy. Nutrition review. 2016; 74 (9): 549-557.

7. Chiarello DI, Marin R, Proverbio F, Coronado P, Toledo F, Salsoso R, et al. Mechanisms of the Effects of Magnesium Salts in Preeclampsia. Placenta. 2018; 69: 134-139.

8. Namitha Vijay. Evaluation of Serum Magnesium Level in Pregnant Women with and without Gestational Diabetes Mellitus. International Journal of Biochemistry and Biophysics. 2018; 6(2): 33-36.

9. American Diabetes Association. Diagnosis and Classification of Diabetes Mellitus [published correction appears in Diabetes Care. 2010 Apr;33(4):e57]. Diabetes Care. 2010;33 Suppl 1(Suppl 1):S62-S69.

10. Abadi Agus. Panduan Penatalaksanaan Kehamilan dengan Diabetes Melitus. 2010. Diunduh dari: https://pogi.or.id/publish/download/pnpk-dan-ppk/.

11. Cunningham, et al. Diabetes Mellitus Chapter 57. Williams Obstetrics 25th edition. 2018.

12. Yang SJ, Hwang SY, Baik SH, Lee KW, Nam MS, Park YS et al. Serum Magnesium Level is Associated with Type 2 Diabetes in Women with a History of Gestational Diabetes Mellitus:The Korea National Diabetes Program Study. J Korean Med Sci. 2014;29:849.

13. Chutia H, Lynrah KG. Association of Serum Magnesium Deficiency with Insulin Resistance in Type 2 Diabetes Mellitus. J Lab Physicians 2015;7:75-8.

14. Gröber U, Schmidt J, Kisters K. Magnesium in Prevention and Therapy. Nutrients. 2015; 7(9): 8199-226.

15. Mishu FA, Muttalib MA, Naher S, Tabassum R, Ahmed R, Aziz Z, Wahab MAKA, Akhter $S$, Khan MRA. Serum Magnesium Level in Gestational Diabetes Mellitus in a Tertiary Care Hospital of Bangladesh. Bangladesh Journal of Medical Biochemistry. 2016;(9):59-62. 


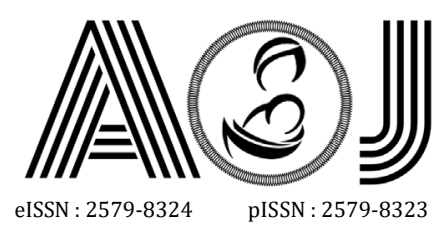

16. Saris NE, Mervaala E, Karppanen H, Khawaja JA, Lewenstam A. Magnesium. An update on Physiological, Clinical and Analytical Aspects. Clinica Chimica Acta; International Journal of Clinical Chemistry. 2000 Apr;294(1-2):1-26.

17. Baloch GH, Khalida S, Mukhtiar HJ, Tahir A, Chandr MD, Bikha RD, Syed ZAS, Kashif F. Serum Magnesium Level During Pregnancy. World Applied Sciences Journal. World Applied Sciences Journal. 2012; 17 (8): 1005-1008.

18. Bardicef M, Bardicef O, Sorokin Y, Altura BM, Altura BT, Cotton D B and Resnick LM. Extracelluar and Intracellular Magnesium Depletion in Pregnancy and Gestational Diabetes. Am J Obst Gynecol. 1995; 172: 1009.

19. Takaya J, Yamato F and Kanelco K. Possible Relationship Between Low Birth Weight and Magnesium Status: from the Standpoint of Fetal Origin Hypothesis. Magnes Res. 2006; 19: 630-9.

20. Wang Y, Tan M, Huang Z, Sheng L, Ge Y, Zhang H, Jiang M. Elemental Contents in Serum of Pregnant Women with Gestational Diabetes Mellitus. Biol Trace Elem Res. 2002; 88(2): 113-118.

21. Musavi H, Mohammadi Tahroodi F, Fesahat F, et al. Investigating the Relationship between Magnesium levels and Diabetes Mellitus in Pregnant Women. Int J Mol Cell Med. 2019; 8(3):223-231.

22. Nabouli MR, Lassoued L, Bakri Z, Moghannem M. Modification of Total Magnesium Level in Pregnant Saudi Women Developing Gestational Diabetes Mellitus. Diabetes \& Metabolic Syndrome. 2016 Oct - Dec;10(4):183-185.

23. Kim DJ, Xun P, Liu K, Loria C, Yokota K, Jacobs DR et al. Magnesium Intake in Relation to Systemic Inflammation, Insulin Resistance, and the Incidence Of Diabetes. Diabetes Care. 2010;33:2604-10.

24. Song Y, Li TY, Van Dam RM, Manson JE, Hu FB. Magnesium Intake and Plasma Concentration of Markers of Systemic Inflammation and Endothelial Dysfunction in Women. Am J Clin Nutr. 2007;85:1068-74.

25. He K, Liu K, Daviglus ML, Morris SJ, Loria CM, Van Horn L et al. Magnesium Intake and Incidence of Metabolic Syndrome Among Young Adults. Circulation. 2006;113:167582.

26. Mishu AF, Muttalib AM. Serum Magnesium and Copper in Bangladeshi Women with Gestational Diabetes Mellitus. IMC J Med Sci. 2017; 11(1):25-8.

27. Al-Auqbi TFR, Al-Mussawi AMR, Al- Sammraie AMR. Serum Copper, Zinc and Cu/ Zn Ratio in Diabetes. Iraqi J. Comm. Med. 2008; 21(1)64-8.

28. Yang SJ, Hwang SY, Baik SH, et al. Serum Magnesium Level is Associated with Type 2 Diabetes in Women with a History of Gestational Diabetes Mellitus: The Korea National Diabetes Program Study. J Korean Med Sci. 2014; 29(1):84-89. 


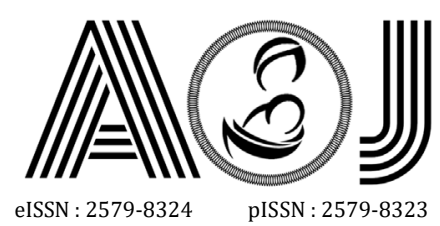
ANDALAS OBSTETRICS AND GYNECOLOGY JOURNAL Address for Correspondence:

Editorial Room Andalas Obstetrics and Gynecology Journal, $3^{\text {rd }}$ floor of KSM of Obstetrics and Gynecology, RSUP DR. M. Djamil Padang, Jl. Perintis Kemerdekaan Padang, Sumatera Barat 25127

Website:

http://jurnalobgin.fk.unand.ac.id/index.php/JOE

29. Paolisso G, Scheen A, D'Onofrio F, Lefèbvre P. Magnesium and Glucose Homeostasis. Diabetologia. 1990; 33:511-514.

30. Takaya J, Higashino H, Kobayashi Y. Intracellular Magnesium and Insulin Resistance. Magnes Res. 2004; 17:126-136.

31. Asemi Z, Karamali M, Jamilian M, et al. Magnesium Supplementation Affects Metabolic Status and Pregnancy Outcomes in Gestational Diabetes: a Randomized, Double-Blind, Placebo-Controlled Trial. Am J Clin Nutr. 2015;102(1):222-229. 